\title{
Molecular Analyses of Citrus tristeza virus Subisolates Separated by Aphid Transmission
}

\author{
R. H. Brlansky, Professor, University of Florida, Citrus Research and Education Center, Lake Alfred; V. D. \\ Damsteegt, Research Plant Pathologist, USDA, ARS, FDWSRU, Fort Detrick, Frederick, MD; and D. S. Howd, \\ Senior Biological Scientist, and A. Roy, Postdoctoral Plant Pathologist, University of Florida, Citrus Research and \\ Education Center, Lake Alfred
}

\begin{abstract}
Brlansky, R. H., Damsteegt, V. D., Howd, D. S., and Roy, A. 2003. Molecular analyses of Citrus tristeza virus subisolates separated by aphid transmission. Plant Dis. 87:397-401.

Citrus tristeza virus (CTV) exists in field isolates as a complex of virus isolates. This complex may contain both mild and severe CTV. Using single and multiple aphid transmissions, subisolates of the various field isolates were separated. Some CTV isolates that tested negative with the monoclonal antibody MCA13 consisted of MCA13-positive subisolates. Using primers to specific and variable regions of the CTV genome, molecular profiles of the isolates and subisolates were generated and compared. The profiles of the subisolates sometimes were very different from the parent field isolates from which they were transmitted.
\end{abstract}

Citrus tristeza virus (CTV) is the causal agent of one of the most destructive diseases of citrus (3). CTV is a complex closterovirus and is the largest of the known plant viruses (19-kb genome), with numerous biological strains present worldwide (15). CTV strains cause symptoms such as stem pitting, decline, and death of sweet orange and grapefruit on sour orange rootstock, seedling yellows, vein clearing, and vein corking (15). These symptoms can occur on different citrus hosts.

Host range tests have been used to categorize the various biological types of CTV. Garnsey et al. (9) defined a standardized biological host range for scoring the different types of CTV. However, quick laboratory methods are needed for detection and separation of CTV strains. Serological methods can detect CTV $(2,5,6,8)$, but do not always discriminate biological activity. The monoclonal antibody MCA13 was the first that could separate severe decline isolates (those that cause decline and death of scions grafted on sour orange rootstock) from mild isolates in Florida (21). However, it is not able to detect all decline or stem pitting isolates (15). Nikolaeva et al. (19) developed specific antibodies and

Corresponding author: R. H. Brlansky

E-mail: rhby@lal.ufl.edu

This research was supported by the Florida Agricultural Experiment Station and grants from USDA, Specific Cooperative Agreement on Exotic Citrus Diseases, and USDA, CSREES, Special Grant on Citrus Tristeza, and approved for publication as Journal Series No. R-08803.

Accepted for publication 25 November 2003.

Publication no. D-2003-0214-03R

(C) 2003 The American Phytopathological Society enzyme-linked immunosorbent assay (ELISA) methods to specifically detect orange stem pitting strains.

CTV isolates have been characterized by their capsid protein gene sequences $(10,17,20)$ and $5^{\prime}$ terminal sequence $(16)$. Comparison of the sequence of a single gene or region may reflect the differences for just that region, but this region may not be reflective of the entire genome. A better understanding of the molecular relatedness of CTV has been obtained by comparison of the complete genomes of fully sequenced isolates. Six CTV isolates are now sequenced: T36 (U16304), T30 (AF260651), T-385 (Y18420), SY568 (AF001623), VT (U569902), and NUagA (AB046398). Comparison of the sequences of VT (18) and T36 (14) indicated that the nucleotide sequences of the two isolates were highly conserved for the $3^{\prime}$ terminal 8,400 nucleotides, but showed a gradual increase in sequence divergence toward the $5^{\prime}$ proximal for the remainder of the 11 kilobases of the genome (16). Sequences of the 5' untranslated region of the genomic RNA of CTV isolates were classified into three types (I, II, and III) (16). The relative frequency of each sequence type was assessed in CTV isolates of different geographic origin and pathogenic characteristics by reverse transcription polymerase chain reaction (RT-PCR) with sets of typespecific primers using CTV dsRNA as template (1). It is difficult to completely sequence the 19-kb CTV genome, and routine comparison of isolates by complete sequencing is impractical. As an alternative, another approach was developed based upon the amplification of multiple molecular markers by the RT-PCR using primers specific for divergent regions of the genomes of two CTV sequence groups
(T36 and Israeli VT type) (13). Hilf et al. (13) classified isolates within these groups into three specific "genotypes" using three sets of primers located in the 5 ' half of the genomic RNA. Analysis of additional isolates from other countries suggested that at least one additional genotype existed that did not react with any of their primers (11).

Two important means of CTV spread are from grafting of virus-infected budwood and aphid transmission (15). The brown citrus aphid (BCA) (Toxoptera citricida) and the melon aphid (Aphis gossypii) are the most important aphid vectors of CTV (15). BCA transmits CTV isolates 6 to 25 times more efficiently than the melon aphid (24). Wherever the BCA has been introduced, severe decline strains of CTV have appeared, and in some instances, stem pitting strains (15). Recently, it has been shown that CTV exists in field trees as a complex of subisolates that cause diverse symptoms $(7,22)$.

In this study, we tested the ability of the BCA to separate the complex of subisolates in three different CTV source isolates and the usefulness of CTV genotypespecific primers (11) to determine the molecular profiles of the source and aphid separated subisolates. Information on what constitutes different CTV complexes and the relationship between the complex and aphid transmission will aid in the development and testing of detection systems for severe CTV.

\section{MATERIALS AND METHODS}

Virus isolates. Naturally occurring Florida CTV isolates FS627 and MCN2d, and a Corsica isolate, B192, were used. The FS627 isolate is a MCA13 positive isolate causing moderate vein clearing in Mexican lime (Citrus aurantiifolia (L.) Swingle), no stem pitting in either sweet orange or grapefruit, and no seedling yellows. Preliminary reports showed it to be a mixture of mild (MCA13 negative) and severe (MCA13 positive) subisolates (S. M. Garnsey, personal communication) and probably representative of a common Florida field isolate. The MCN2d isolate is MCA13 negative and produces mild vein clearing in Mexican lime, no stem pitting, and no sweet orange on sour orange decline (9). It was chosen since it appears to be mild but could contain hidden severe subisolates. The B192 isolate is a MCA13 
positive isolate from the USDA, Beltsville Exotic Citrus Disease Collection, and has been described by Bove et al. (4). Its original source is Kumquat K123 in Corsica, and it causes mild or no symptoms in Mexican lime, no vein clearing or stem pitting, and was reported as having no natural transmission in the field or with 100 A. gossypii (4). It was chosen for this study because of its lack of aphid transmissibility. The parent isolates were maintained by budding onto glasshouse-grown sweet orange or Mexican lime seedlings (23). The single and multiple aphid transmissions from plants infected by these isolates are referred to as subisolates, rather than strains, because they may still be a mixture.

Aphid transmission. Apterous BCA were maintained on virus-free Carrizo citrange seedlings. Groups of 30 to 50 aphids were fed on CTV bud-inoculated (23) sweet orange or Mexican lime seedlings infected with virus isolates listed above. Acquisition access periods of $24 \mathrm{~h}$ at a photosynthetic active radiation (PAR) $4.64 \mu \mathrm{mol} \cdot \mathrm{m}^{-2} \cdot \mathrm{s}^{-1}$ and $25^{\circ} \mathrm{C}$ were used. Aphids were then placed, using \#00 Red Sable brushes (Ted Pella Inc., Redding, CA), singly or multiply on virus-free sweet orange or Mexican lime seedlings $\left(25^{\circ} \mathrm{C}\right.$, PAR of $4.64 \mu \mathrm{mol} \cdot \mathrm{m}^{-2} \cdot \mathrm{s}^{-1}$ for $9 \mathrm{~h}$ ). After an inoculation access period of $24 \mathrm{~h}$, the aphids were killed by spraying with an aphidicide ( $0.25 \%$ Malathion), and the plants were grown in an insect-free shaded glasshouse at a PAR of $558 \mu \mathrm{mol} \cdot \mathrm{m}^{-2} \cdot \mathrm{s}^{-1}$ (day) and 28 to $30^{\circ} \mathrm{C}$.

Serology assays. Samples of CTVinfected source plants and receptor plants were assayed for CTV using double antibody sandwich (DAS)-ELISA (2). The rabbit polyclonal antibody $1052(1 / 10,000)$ was used. This antibody was made using CTV isolate T36 and reacts with all CTV isolates. Positive controls were T36infected Mexican lime tissues. Healthy Mexican lime and sample extraction buffer (PBS-Tween with $0.2 \%$ polyvinyl pyrrolidone) were used as negative and buffer controls. Two hundred microliters per well were used. The $\mathrm{OD}_{405}$ values of the buffer were subtracted from all $\mathrm{OD}_{405}$ values obtained. Plants were considered positive if the $\mathrm{OD}_{405}$ value was four times the healthy control. All DAS-ELISA positive plants were further tested using mouse monoclonal antibody MCA13 (21). The same positive and negative controls above were used along with the mild CTV isolate T26, which does not react with antibody MCA13 (21).

Nucleic acid extraction. Total plant RNA was isolated from CTV-infected and healthy leaves and bark of sweet orange and Mexican lime using the RNeasy Plant Mini Kit (QIAGEN, Valencia, CA) following the manufacturer's protocol.

Primers. Eleven sets of primers developed by Hilf et al. (13)-T36CP, T36Pol, T36-5' T36-k17, T30Pol, T30-5', T30-kl7, VT-Pol, VT-5', VT-k17, and T3-k17-were synthesized (Integrated DNA Technologies Inc., Coralville, IA) and used for specific region amplification of CTV isolates and their subisolates. The primers designated k17 and 5' were from open reading frame (ORF) 1a, primers Pol were from ORF $1 \mathrm{~b}$ and ORF 2, and CP was from ORF 7 of the CTV isolate T36 as diagrammed by Hilf et al. (13).

Reverse transcription. The first strand of cDNA was synthesized from the total RNA extracted from CTV-infected and healthy tissues. Ten microliters from the total extracted RNA was added to $1 \mu \mathrm{l}$ of $10 \mu \mathrm{M}$ of the antisense primer, mixed, and then microfuged at $13,600 \times g$ for $10 \mathrm{~s}$. The preparation was incubated for $10 \mathrm{~min}$ at $70^{\circ} \mathrm{C}$ and then transferred to ice for 5 min. A mixture consisting of $5 \times 1$ st strand buffer, $0.1 \mathrm{M}$ dithiothreitol, $10 \mathrm{mM}$ dNTP (Promega, Madison, WI), and sterile distilled water was prepared. This mixture was incubated for 2 to $3 \mathrm{~min}$ at $42^{\circ} \mathrm{C}$ and removed to room temperature $\left(24^{\circ} \mathrm{C}\right)$. To this was added 20 units of Superscript II RNase H-Reverse transcriptase (Invitrogen, Carlsbad, CA) and 40 units of rRNasin (Promega, Madison, WI), and this was microfuged at $13,600 \times g$ for $10 \mathrm{~s}$. Nine microliters of this cocktail mixture was added to each tube containing the RNA preparation. The $20-\mu \mathrm{l}$ total contents were gently mixed, incubated at $50^{\circ} \mathrm{C}$ for 1 $\mathrm{h}$, and then held at $72^{\circ} \mathrm{C}$ for $15 \mathrm{~min}$. The mixture was microfuged at $13,600 \times g$ for $10 \mathrm{~s}$ and held on ice.

PCR amplification with sequence specific CTV primers. The cDNA was purified using a QIA quick PCR purification kit from QIAGEN. Three to five microliters of cDNA was amplified in a 50- $\mu \mathrm{l}$ reaction volume containing 5 units of Taq DNA polymerase (Promega), $25 \mathrm{mM}$ $\mathrm{MgCl}_{2}, 0.2 \mathrm{mM}$ each of dATP, dCTP, $\mathrm{dGTP}$, and dTTP (Promega), and $10 \mu \mathrm{M}$ of each primer. PCR was performed in a programmable thermal controller (Model HBPX 110, PCR Express, Hybaid Limited, Middlesex, UK) using the following parameters: one cycle at $94^{\circ} \mathrm{C}$ for $2 \mathrm{~min}, 30$ cycles at $94^{\circ} \mathrm{C}$ for $30 \mathrm{~s}$ (denaturation), $55^{\circ} \mathrm{C}$ for $30 \mathrm{~s}$ (annealing), and $72^{\circ} \mathrm{C}$ for 45 $\mathrm{s}$ (primer extension), followed by one cycle at $72^{\circ} \mathrm{C}$ for $5 \mathrm{~min}$. PCR products were analyzed on $1 \%$ agarose gels containing $200 \mathrm{ng}$ of ethidium bromide per ml.

Interpretation of generated PCRmarker profiles. Hilf and Garnsey (11)

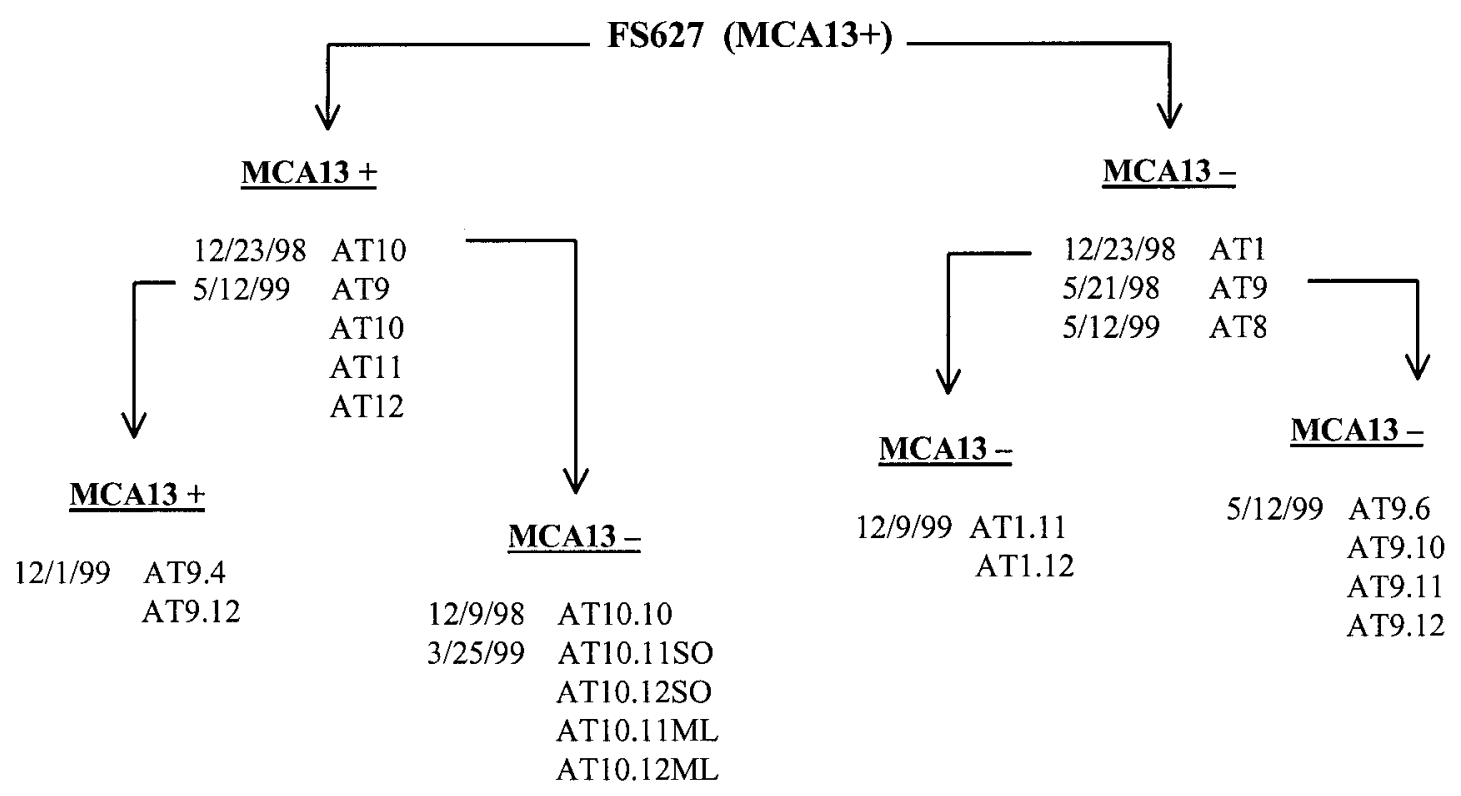

Fig. 1. Response of Citrus tristeza virus (CTV) subisolates to CTV monoclonal antibody MCA13 that were derived by aphid transmission from Florida CTV isolate FS627. 
reported on a method to classify and characterize CTV isolates based on PCRamplification of 11 molecular markers using primers derived from the sequenced genomes of CTV isolates T36, T30, VT, and T3. The method utilizes all 11 markers, generating a profile for each isolate or subisolate tested. Depending on the profile generated, the isolate can then be placed into one of the genotype groups. The primers for the capsid protein were obtained from the sequence of isolate T36, and this is considered to be a general marker for CTV and is not used for isolate discrimination. According to Hilf and Garnsey (11), primer pairs derived from the T36 genomic sequence amplifies products from only T36 cDNA. An isolate was designated as a T36 genotype if it reacted with at least the PCR marker for the T36Pol; however, it may not react with all the T36 markers. T30 genotypes and VT genotypes also were designated if reactions occurred with the T30Pol and VT-Pol markers, respectively. Other positive reactions may occur; that is to say, T30 genotypes may react with VT-k17 and VT5' markers, and VT genotypes may react with the T30-k17 marker. T3 genotypes should react with T3-k17 but also with the VT-Pol and/or with the VT5' markers. It is important that the profile is considered, not the reaction to just one or two PCR markers.

\section{RESULTS}

Aphid transmissions. Fourteen subisolates were obtained from the CTV FS627 isolate (Fig. 1). More MCA13 negative than positive subisolates were recovered. Transmissions from CTV MCN2d yielded fewer subisolates; however, both MCA13 positive and negative subisolates were obtained (Fig. 2). The B192 CTV isolate was transmitted using BCA. Single aphid transmissions yielded the subisolates shown in Table 1. As indicated, some of these subisolates produced severe symptoms in Mexican lime. In plant inoculation tests, where buds from the aphid- transmitted subisolate plants were used to inoculate various citrus hosts, the same symptoms were produced in Mexican limes (Table 1). In addition, the CTV subisolate B192 5.4 produced stem pitting symptoms in sweet orange and grapefruit and decline in sweet orange on sour orange rootstock, all of which indicate a severe CTV strain. These symptoms were not caused when buds from the B192 source plant material were used to inoculate the same citrus host species.

Table 1. Host reactions of Citrus tristeza virus (CTV) isolate B192 and its aphid transmitted subisolates

\begin{tabular}{lccc}
\hline CTV & Mexican lime & Grapefruit & Sweet orange \\
\hline B192-source & NS $^{\text {a }}$ & NS & NS \\
B192.4*b & LC; SVC & SY & NS \\
B192.4.4** & LC, SVC & SY & NS \\
B192.5* & SVCC & ND & ND \\
B192.5.4** & SVCC & SY; SP & SP \\
B192.6* & VC & SY & ND \\
B192.8* & SVC & SP & NS \\
B192.8.5** & SVC & SP & NS \\
\hline
\end{tabular}

a NS = no symptom; $\mathrm{LC}=$ leaf chlorosis; $\mathrm{VC}=$ vein clearing; $\mathrm{SVC}=$ strong vein clearing; $\mathrm{SVCC}=$ strong vein clearing and vein corking; $\mathrm{SY}=$ seedling yellows; $\mathrm{SP}=$ stem pitting; $\mathrm{ND}=$ no data.

$\mathrm{b} *$ = first level single aphid transmitted subisolate denoted by B192.\#. $* *=$ second level single aphid transmitted subisolate denoted by B192.\#.\#.

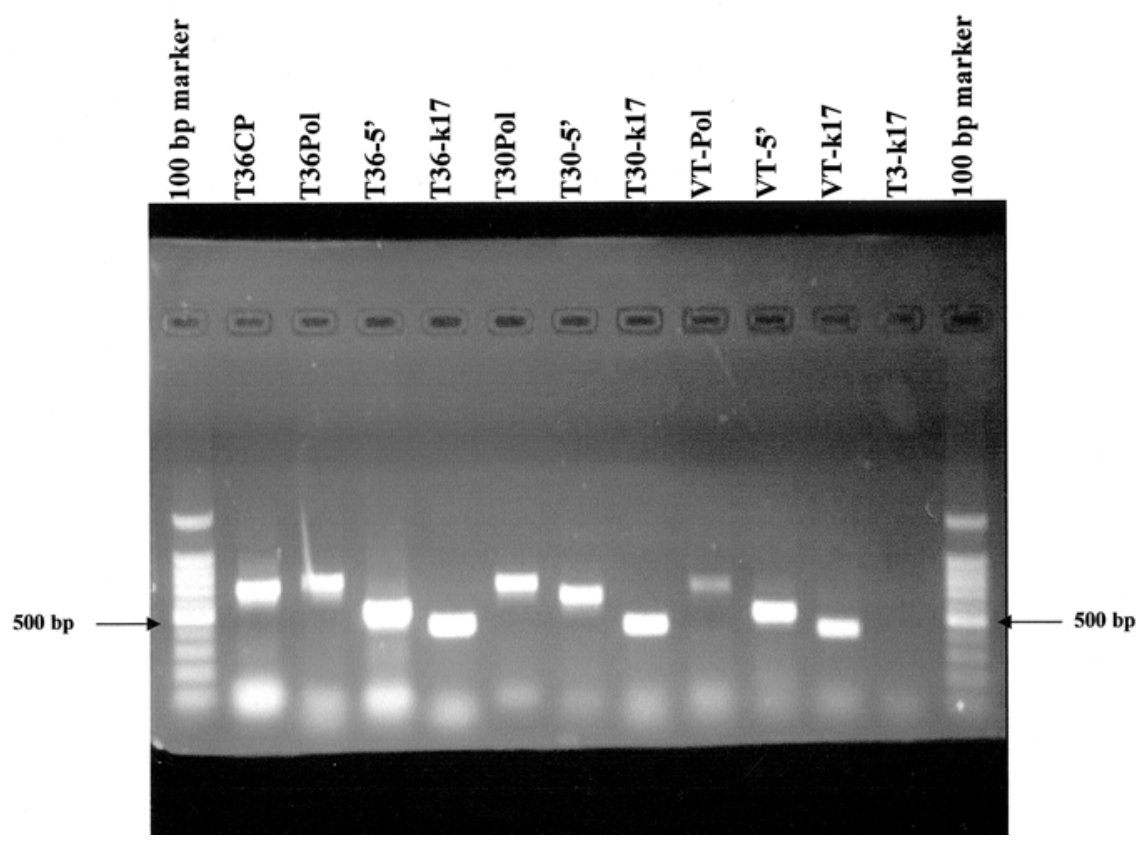

Fig. 3. Molecular marker profile of Florida Citrus tristeza virus (CTV) isolate FS627.
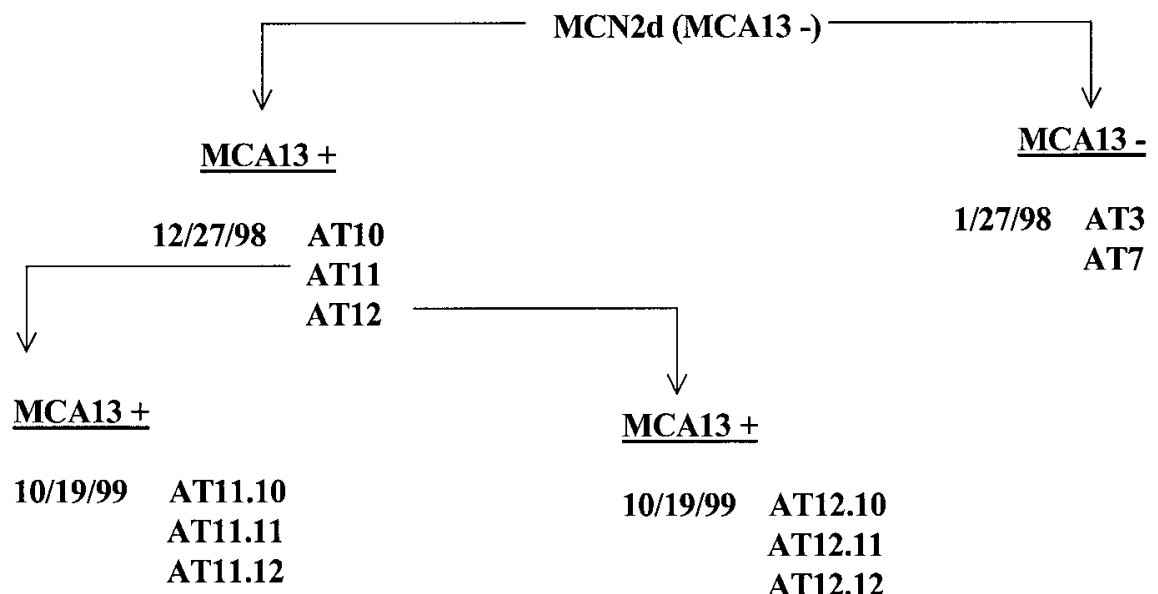

$\underline{\operatorname{MCA13}+}$

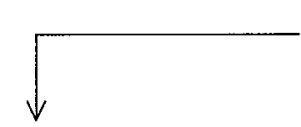

AT10 AT11 AT12
1/27/98 AT3 AT7

\section{$\underline{\text { MCA13- }}$}

10/19/99 AT3.12 $\underline{\text { MCA13 + }}$

\section{0/19/99 AT12.10 \\ AT12.11 \\ AT12.12}

Fig. 2. Aphid transmission of Citrus tristeza virus (CTV) subisolates from the Florida isolate MCN2d and the different reactions obtained with CTV monoclonal MCA13 antibody. 
Serology assays. All source plants were positive for CTV using the polyclonal antibody 1052. Source plants FS627 and B192 were positive with the antibody MCA13. The MCN2d source plant tested negative using this antibody (data not shown).

Molecular profiles. The molecular profiles of Florida CTV isolate FS627 and its subisolates are shown in Figure 3 and Table 2. The FS627 isolate contained a mixture of T36, T30, and VT genotypes but not the T3 genotype (Fig. 3). SAT subisolates contained either the T30 genotype, a combination of T36/T30 genotype, or a combination of the T30/VT genotype (Table 2). No subisolate contained the VT or the T36 genotype alone, and there were no reactions with the T3 genotype marker (12). Subisolates from the primary (first level) aphid transmissions contained a mixture of the T36 and T30 genotypes or were just the T30 genotype. The VT genotype was found only in transmissions from the second level aphid transmissions (Table 2).

The profile of the B192 isolate was a mixture of T30 and VT genotypes (Table 3). The single aphid transmitted subisolates were a mixture of T30, VT, and T3 genotypes. The MCN2d isolate was a mixture of T36 and T30 genotypes (Table 4). Subisolates separated from this isolate were a mix of both T30 and VT genotypes or only the VT genotype.

\section{DISCUSSION}

The BCA is a useful tool to separate the complex of CTV subisolates (strains) that exists in many field isolates. The reason for this is unknown. The detection of severe subisolates hidden within the mild symptom isolates is important for understanding CTV. The presence of hidden severe CTV was documented by Broadbent et al. (7), using single BCA transmission as

Table 2. Reverse transcription-polymerase chain reaction (RT-PCR) molecular marker profiles of Florida Citrus tristeza virus (CTV) isolate FS627 and its transmitted subisolates

\begin{tabular}{|c|c|c|c|c|c|c|c|c|c|c|c|c|}
\hline \multirow[b]{2}{*}{ CTV isolates } & \multicolumn{12}{|c|}{ RT-PCR markers } \\
\hline & MCA13 $^{a}$ & T36CP & T36Pol & T36-5' & T36-k17 & T30Pol & T30-5' & T30-k17 & VT-Pol & VT-5' & VT-k17 & T3-k17 \\
\hline FS627 & $t^{\mathrm{b}}$ & + & + & + & + & + & + & + & + & + & + & - \\
\hline AT9 (5/21/98) & - & + & + & - & + & - & + & + & - & - & + & - \\
\hline AT9 (5/12/99) & + & + & + & + & + & + & + & + & - & + & + & - \\
\hline AT10 (12/23/97) & + & + & + & + & - & + & + & + & - & - & - & - \\
\hline AT1 (12/23/97) & - & + & - & - & - & + & + & + & - & - & - & - \\
\hline AT10.10 (12/9/98) & - & + & - & - & + & + & + & + & + & + & + & - \\
\hline AT10.11 (12/9/98) & - & + & - & - & + & + & + & + & - & + & + & - \\
\hline AT9.4 $(12 / 1 / 99)$ & + & + & - & - & - & + & + & + & - & + & + & - \\
\hline AT9.6 (5/12/99) & - & + & - & - & + & + & + & + & + & + & + & - \\
\hline AT9.10 (5/12/99) & - & + & + & - & - & + & + & + & - & - & - & - \\
\hline AT9.11 (5/12/99) & - & + & - & + & + & + & + & + & + & + & + & - \\
\hline AT9.12 (5/12/99) & - & + & - & - & + & + & + & + & + & + & + & - \\
\hline AT9.12 (12/1/99) & + & + & + & + & + & - & - & + & + & + & + & - \\
\hline AT1.11 (12/1/99) & - & + & + & - & - & + & + & + & - & - & + & - \\
\hline AT1.12 (12/1/99) & - & + & - & - & + & + & + & + & + & + & + & - \\
\hline
\end{tabular}

${ }^{a}$ Monoclonal antibody MCA13. $+=$ positive MCA13 reaction, and $-=$ negative MCA13 reaction in double-antibody sandwich enzyme-linked immunosorbent assay (DAS-ELISA).

${ }^{\mathrm{b}}+=$ positive band in RT-PCR. $-=$ no band in RT-PCR.

Table 3. Reverse transcription-polymerase chain reaction (RT-PCR) molecular marker profiles of Citrus tristeza virus (CTV) isolate B192 and its aphid transmitted subisolates

\begin{tabular}{|c|c|c|c|c|c|c|c|c|c|c|c|c|}
\hline \multirow[b]{2}{*}{ CTV isolates } & \multicolumn{12}{|c|}{ RT-PCR markers } \\
\hline & MCA13 $^{a}$ & T36CP & T36Pol & T36-5' & T36-k17 & T30Pol & T30-5' & T30-k17 & VT-Pol & VT-5' & VT-k17 & T3-k17 \\
\hline B192 & $t^{\mathrm{b}}$ & + & - & - & - & + & + & + & + & + & + & - \\
\hline B192.8 & + & + & - & - & - & - & + & + & + & + & + & + \\
\hline B192.8.5 & + & + & - & - & + & + & + & + & + & + & + & + \\
\hline B192.5.4 & + & + & + & - & + & + & - & + & + & + & + & + \\
\hline B192.6 & + & + & - & - & - & + & + & + & + & - & + & + \\
\hline B192.4 & + & + & - & - & + & + & + & + & + & - & + & + \\
\hline B192.4.4 & + & + & - & - & - & - & + & + & + & + & + & + \\
\hline
\end{tabular}

${ }^{\text {a }}$ Monoclonal antibody, MCA13, double-antibody sandwich enzyme-linked immunosorbent assay (DAS-ELISA) results: $+=$ positive reaction, $-=$ negative reaction.

${ }^{\mathrm{b}}+=$ positive band in RT-PCR. $-=$ no band in RT-PCR.

Table 4. Reverse transcription-polymerase chain reaction (RT-PCR) molecular marker profiles of Florida Citrus tristeza virus (CTV) MCN2d and its aphid transmitted subisolates

\begin{tabular}{|c|c|c|c|c|c|c|c|c|c|c|c|c|}
\hline \multirow[b]{2}{*}{ Isolates } & \multicolumn{12}{|c|}{ RT-PCR markers } \\
\hline & MCA13 $^{a}$ & T36CP & T36Pol & T36-5' & T36-k17 & T30Pol & T30-5' & T30-k17 & VT-Pol & VT-5' & VT-k17 & T3-k17 \\
\hline $\mathrm{MCN} 2 \mathrm{~d}$ & $-^{\mathrm{b}}$ & + & - & + & - & - & + & - & - & - & + & - \\
\hline AT11 & + & + & - & + & - & + & + & + & + & - & + & - \\
\hline AT12 & + & + & - & - & - & + & + & + & + & + & + & - \\
\hline AT3 & - & + & - & - & - & - & - & + & + & + & + & - \\
\hline AT7 & - & + & - & - & - & - & - & - & + & + & + & - \\
\hline
\end{tabular}

a Monoclonal antibody, MCA13, double-antibody sandwich enzyme-linked immunosorbent assay (DAS-ELISA) results: $+=$ positive reaction, $-=$ negative reaction.

${ }^{\mathrm{b}}+=$ positive base pair band in RT-PCR. $-=$ no band in RT-PCR. 
a tool for separation. Most Australian isolates that contained severe stem pitting subisolates also would contain mild stem pitting. In our study, we found severe decline, MCA13 positive, subisolates hidden within MCA negative isolates. We also documented the presence of severe stem pitting subisolates hidden within the mild symptom producing B192 isolate. Isolate B192 produced no severe symptoms on biological indicators.

The presence of hidden severe CTV within mild isolates has major regulatory implications since specific detection methods are currently unavailable for all severe CTV isolates. Using the primers developed by Hilf et al. (13), a mixture of genotypes was found in many of the isolates and in many of the subisolates separated by aphid transmission. Sometimes unexpected mixtures of genotypes were discovered (Tables 1 to 4$)$. The presence of the VT genotype in the FS627 source isolate, the B192 source isolate, and the MCN2d subisolates was not expected since VT genotype isolates have not been previously reported from these areas. Hilf and Garnsey (11) reported no instances of a mixture of genotypes such as T36 and a T30 and a VT. Many of the aphid transmitted subisolates still contained a mixture of the genotypes; however, two subisolates from the FS627 were the T30 genotype and two subisolates from the MCN2d isolate were only the VT genotype. The reason for the inability to detect the VT genotype (in numerous attempts) in the MCN2d parent isolate is unknown. Why the VT genotype was found only after aphid transmission also is unknown. The T36 genotype was transmitted only in conjunction with T30 and VT genotypes. Low transmission rates of 1 to $2 \%$ have been found with the isolate T36 (R. H. Brlansky, unpublished data). More research is needed on the population of various strains present in CTV complexes, the selective transmission of severe CTV by BCA, and the influence of host and sampling time on subisolates detection.

\section{LITERATURE CITED}

1. Ayllon, M. A., Lopez, C., Navas-Castillo, J., Garnsey, S. M., Guerri, J., Flores, R., and Moreno, P. 2001. Polymorphism of the $5^{\prime}$ termi- nal region of citrus tristeza virus (CTV) RNA: Incidence of three sequence types in isolates of different origin and pathogenicity. Arch. Virol. 146:27-40.

2. Bar-Joseph, M., Garnsey, S. M., Gonsalves, D., Moscovitz, M., and Purciful, D. E. 1979. The use of enzyme-linked immunosorbent assay for detection of citrus tristeza virus. Phytopathology 69:190-194.

3. Bar-Joseph, M., Marcus, R., and Lee, R. F. 1989. The continuous challenge of citrus tristeza virus control. Annu. Rev. Phytopathol. 27:291-316.

4. Bove, C., Vogel, R., Albertini, D., and Bove, J. M. 1988. Discovery of a strain of tristeza virus $(\mathrm{K})$ inducing no symptoms in Mexican lime. Pages 14-16 in: Proc. Conf. IOCV, 10th. L. W. Timmer, S. M. Garnsey, and L. Navarro, eds. IOCV, Riverside, CA.

5. Brlansky, R. H., Garnsey, S. M., Lee, R. F., and Purcifull, D. E. 1984. Application of citrus tristeza virus antisera in labeled antibody, immuno-electron microscopical and sodium dodecyl immunodiffusion tests. Pages 337342 in: Proc. Conf. IOCV, 9th. S. M. Garnsey, L. W. Timmer, and J. A. Dodds, eds. IOCV, Riverside, CA.

6. Brlansky, R. H., Lee, R. F., and Garnsey, S. M. 1988. In situ immunofluoresecence for the detection of citrus tristeza virus inclusion bodies. Plant Dis. 72:1039-1041.

7. Broadbent, P., Brlansky, R. H., and Indsto, J. 1996. Biological characterization of Australian isolates of citrus tristeza virus and separation of subisolates by single aphid transmissions. Plant Dis. 80:329-333.

8. Garnsey, S. M., Gonsalves, D., and Purcifull, D. E. 1979. Rapid diagnosis of citrus tristeza virus infection by SDS-immunodiffusion procedures. Phytopathology 69:88-95.

9. Garnsey, S. M., Gumpf, D. J., Roistacher, C. N., Civerolo, E. L., Lee, R. F., Yokomi, R. K., and Bar-Joseph, M. 1987. Toward the standardized evaluation of the biological properties of citrus tristeza virus. Phytophylatica 19:151-158.

10. Gillings, M., Civerolo, E. L., Gumpf, D. J., Yokomi, R. K., and Lee, R. F. 1993. Characterization of isolates and strains of citrus tristeza closterovirus using restriction analysis of the coat protein gene amplified by polymerase chain reaction. J. Virol. Methods 44:305-317.

11. Hilf, M. E., and Garnsey, S. M. 2000. Characterization and classification of citrus tristeza virus isolates by amplification of multiple molecular markers. Pages 18-27 in: Proc. Conf. IOCV, 14th. IOCV, Riverside, CA.

12. Hilf, M. E., Gum, D., and Garnsey, S. M. 2001. Florida isolates of CTV in commercial plantings show limited genetic variability. Page 26 in: Proc. Conf. IOCV, 15th. (Abstr.) IOCV, Riverside, CA.
13. Hilf, M. E., Karasev, A. V., Albiach-Marti, M. R., Dawson, W. O., and Garnsey, S. M. 1999. Two paths of sequence divergence in the citrus tristeza virus complex. Phytopathology 89:336-342.

14. Karasev, A. V., Boyko, V. P., Gowda, S., Nikolaeva, O. N., Hilf, M. E., Koonin, E. N., Niblett, C. L., Cline, K., Gumpf, D., Lee, R. F., Garnsey, S. M., Lewandowski, D. J., and Dawson, W. O. 1995. Complete sequence of citrus tristeza virus genome. Virology 208:511-520.

15. Lee, R. F., and Bar-Joseph, M. 2000. Tristeza Pages 61-63 in: Compendium of Citrus Diseases, 2nd ed. L. W. Timmer, S. M. Garnsey, and J. H. Graham, eds. American Phytopathological Society, St. Paul, MN.

16. Lopez, C., Ayllon, M. A., Navas-Castillo, J., Guerri, J., Moreno, P., and Flores, R. 1998. Molecular variability of the $5^{\prime}-$ and $3^{\prime}$ terminal regions of citrus tristeza virus RNA. Phytopathology 88:685-691.

17. Mawassi, M. E., Gafny, R., and Bar-Joseph, M. 1993. The nucleotide sequence of coat protein gene of citrus tristeza virus: Comparison of biologically diverse isolates collected in Israel. Virus Genes 7:265-275.

18. Mawassi, M. E., Mietkiewska, E., Gofman, R., Yang, G., and Bar-Joseph, M. 1996. Unusual sequence relationships between two isolates of citrus tristeza virus. J. Gen. Virol 77:2359-2364

19. Nikolaeva, O. V., Karasev, A. V., Garnsey, S. M., and Lee, R. F. 1998. Serological differentiation of the citrus tristeza virus isolates causing stem pitting in sweet orange. Plant Dis. 82:1276-1280.

20. Pappu, H. R., Pappu, S. S., Niblett, C. L., Lee, R. F., and Civerolo, E. 1993. Comparative sequence analysis of the coat protein of biologically distinct citrus tristeza closterovirus isolates. Virus Genes 7:255-264.

21. Permar, T. A., Garnsey, S. M., Gumpf, D. J., and Lee, R. F. 1990. A monoclonal antibody that discriminates strains of citrus tristeza virus. Phytopathology 80:224-228.

22. Rocha-Pena, M. A., Lee, R. F., Lastra, R., Niblett, C. L., Ochoa-Corona, F. M., Garnsey, S. M., and Yokomi, R. K. 1995. Citrus tristeza virus and its aphid vector Toxoptera citricida. Plant Dis. 79:437-445.

23. Roistacher, C. N. 1991. Tristeza. Pages 17-33 in: Graft-transmissible diseases of citrus handbook for detection and diagnosis. Food Agric. Organ. United Nations, Rome.

24. Yokomi, R. K., Lastra, R., Stoetzel, M., Damsteegt, V. D., Lee, R. F., Garnsey, S. M. Gottwald, T. R., Rocha-Pena, M. A., and Niblett, C. N. 1994. Establishment of the brown citrus aphid Toxoptera citricida (Kirkaldy) (Homoptera: Aphididae) in Central America and the Caribbean basin and its transmission of citrus tristeza virus. J. Econ. Entomol. 87:1078-1085. 